\title{
Farm to Non-Farm Employment Linkages and Pattern: An Analysis of Village Level Survey in Bangladesh*
}

\author{
Ranjit Kumar Sarkar \\ Government of the People's Republic of Bangladesh, Dhaka, Bangladesh \\ M. A. Sattar Mandal \\ Bangladesh Agricultural University, Mymensingh, Bangladesh
}

\begin{abstract}
The widening of rural-urban continuum has accelerated the transformation of Bangladesh agriculture from subsistence toward commercialization. This has accompanied significant employment linkages and patterns in farm and non-farm sector. Modern rice production contributed to employment generation through backward and forward linkages. The field study of three villages measures farm to non-farm employment linkages for two major rice crops. The estimated backward, forward, and total linkages were $0.18,0.43$, and 0.61 for Boro rice and $0.14,0.39$, and 0.53 for Aman rice. For two crops as a whole, farm to non-farm total employment linkage coefficient was 0.58 , which meant that total 100 man days of farm employment per hectare in farm production activities generated 58 man days of non-farm employment in various support services, processing, and marketing activities. Employment pattern in different months was more flexible for the farm workers than for non-farm workers. The availability of farm employment in a month varied from five to 25 days for farm workers, and from 22 to 27 days for non-farm workers. The findings imply that more investment in rice-based production system significantly increases non-farm employment opportunities. From national policy perspective, more research and development efforts should go into accelerating potential rural growth and non-farm sector development.
\end{abstract}

Keywords: rural non-farm employment, backward linkage, forward linkage, direct backward linkage, indirect backward linkage employment

Most of the people of Bangladesh still live in rural areas. The earning members of the rural households are engaged in both farm and non-farm activities. Farm activities mean whole range of activities in crop and non-crop activities including family and hired labour. Non-farm activities include mainly rural trade, agribusiness, manufacturing, construction, transport, and agro-processing services. Bangladesh agriculture has been undergoing a process of gradual transformation from traditional subsistence stage toward

\footnotetext{
* This study was financed by Social Science Research Council (SSRC), Ministry of Planning, Government of the People's Republic of Bangladesh.

Ranjit Kumar Sarkar, Ph.D., senior assistant chief, Ministry of Local Government, Rural Development and Cooperatives, Government of the People's Republic of Bangladesh; research fields: irrigation economics, rural non-farm, project management. E-mail: ranjits1966@yahoo.com.

Corresponding author: M. A. Sattar Mandal, Ph.D., professor, Department of Agricultural Economics, Bangladesh Agricultural University, Mymensingh, Bangladesh; research fields: agricultural technology and institutions, rural economic growth, irrigation and water resource management, agri business, public policies. E-mail: asmandal11@gmail.com.
} 
commercialization, which is characterized by various forms of backward and forward linkages between farm and rural non-farm sectors. The rapid expansion of modern rice technologies demands various services, i.e., irrigation pumps, power tillers, rice transplanting and thresher machines, transportation and marketing services in a dynamic setting (Mandal, 2003). Although, there is a general agreement on the potential links between farm and non-farm sectors in the process of economic growth, it is important to understand the magnitude of such linkages between sectors (Haggblade, Hammer, \& Hazell, 1991).

The share of non-farm employment in Bangladesh is increasing day to day. According to LFS (Labour Force Survey) data, the employment in agricultural sub-sector declined from $63 \%$ in 1995/1996 to 52\% in $2005 / 2006$. On the other hand, non-agricultural employment rose from $37 \%$ to $48 \%$ during the same period (Bangladesh Bureau of Statistics [BBS], 1996; BBS, 2008). This indicates increasing work opportunities in the rural non-farm sector as a result of growth and diversity of agricultural enterprises. Earlier studies also revealed significant growth of non-farm activities within the rural areas and also in the small urban and peri-urban areas of large metropolitan towns (Hossain, Rahman, \& Bayes, 1994; Shilpi, 1998; World Bank, 2004).

There are linkages between farm and non-farm employment. Again the linkages are disaggregated into direct and indirect backward and forward employment linkages. For production and distribution purposes, some work time is spent for acquiring inputs and marketing outputs, which are considered as direct backward and forward non-farm employment respectively, whereas some other work time is spent to supply inputs and sell outputs, which are considered as indirect backward and forward non-farm employment. There are various other actors like traders and service providers who need to spend time in selling inputs, i.e., seed, fertilizer, insecticide, pesticide, agricultural machineries, irrigation equipment spare parts, diesel, mobile, etc., or providing services for producing or repairing activities and buying output, which we call indirect backward and forward employment.

At the household level, there may be one or more earning members who are full time involved in farm work, while others may be full time non-farm employee and vice versa. Also non-farm employment pattern does not remain the same throughout the year. Employment pattern varies from month to month, although empirical knowledge on month wise pattern of non-farm work is scanty.

The discussion above raises the pertinent question as to whether it is possible to create additional employment in non-farm sector without expanding employment opportunities in farm sector. If there is a linkage between farm and non-farm employment, one may wonder how much and what type of linkage prevails and what is the seasonal pattern of rural employment in farm and non-farm sector.

The main objective of the present paper is to measure the magnitudes of farm and non-farm employment linkages and their seasonal pattern using village survey data from Bangladesh. Because the non-farm employment has been receiving priority in many developing countries, as a way of employment diversification, the conclusions drawn from this study could be applicable for similar rural areas of Bangladesh and other developing economies.

\section{Methodology}

\section{Study Area and Household}

The present study is based on the year-round primary data collected from households in three villages — peri-urban fringes, near rural town, and near rural market—during the year 2007-2008. The villages were selected following a stepwise approach giving emphasis on poverty incidence, intensity of farm related 
non-farm enterprises, and rural biasness. For measuring farm to non-farm backward and forward employment linkages 20 mixed non-farm households were selected. Data were collected for two high yielding varieties of rice - irrigated Boro rice grown in dry season (January to June) and rain-fed Aman rice grown in wet season (July to December). To determine pattern of rural non-farm employment, 40 households having no cultivable land were considered. Out of 280 households, 154 were landless households. Among landless households, 77 were non-farm landless households. From 77 non-farm landless households, 40 households were selected for collecting data with respect to determine employment, income, and expenditure pattern.

\section{Measurement of Backward and Forward Employment Linkages}

Rural farm to non-farm backward employment linkage was measured as a ratio of direct and indirect non-farm employment to total farm employment created for the inter-cultural operations or input supplies for rice production. Rural farm to non-farm forward employment linkage effect was measured as a ratio of direct and indirect non-farm employment for rice post-harvest activities, i.e., storing, processing, and marketing to total employment in producing that amount of output with a specific land size and time period. Employment linkages were measured using the following formula: An early exposition by Sarkar, Mandal, and Kleinke (2013) was put in tropentag (2013-Book of Abstract, ID-239, Page-19).

\section{Farm to Non-Farm Backward Employment Linkage}

$$
\mathrm{BEL}_{\mathrm{t}}=\frac{\sum_{\substack{\mathrm{i}=1 \\ \mathrm{i}}}^{\mathrm{n}} \mathrm{\sum}_{\substack{\mathrm{i}=1 \\ \mathrm{i}}}^{\mathrm{n}} \mathrm{Z}_{\mathrm{i}}}{\sum_{\substack{\mathrm{i} \\ \mathrm{n}}}^{\mathrm{n}} \mathrm{X}_{\mathrm{i}}}
$$

Where, $\mathrm{BEL}_{\mathrm{t}}$ is the backward employment linkage, $\mathrm{X}$ stands for the amount of labour (mandays) required for farm activities in producing rice, $Y$ stands for the amount of labour or employment (mandays) required for direct backward non-farm activities in producing rice, $\mathrm{Z}$ stands for the amount of labour or employment (mandays) required for indirect backward non-farm activities in producing rice, $i$ stands for number of activities ranging from 1 to $\mathrm{n}$ and $\mathrm{t}$ stands for time period (time is generally considered as a crop season).

\section{Farm to Non-Farm Forward Employment Linkage}

$$
\mathrm{FEL}_{\mathrm{t}}=\frac{\sum_{\substack{\mathrm{i}=1 \\ \mathrm{n}}}^{\mathrm{n}}+\sum_{\substack{\mathrm{i}=1 \\ \mathrm{i}}}^{\mathrm{n}} \mathrm{Z}_{\mathrm{i}=1}}{\sum_{\substack{\mathrm{i} \\ \mathrm{i}}}^{\mathrm{n}}}
$$

Where, $\mathrm{FEL}_{\mathrm{t}}$ is the forward employment linkage, $\mathrm{X}$ stands for the amount of labour or employment (mandays) required for farm activities in producing rice, $\mathrm{Y}$ stands for the amount of labour or employment (mandays) required for direct forward non-farm activities in producing rice, $\mathrm{Z}$ stands for the amount of labour or employment (mandays) required for indirect forward non-farm activities in producing rice, i stands for number of activities ranging from 1 to $\mathrm{n}$, and $\mathrm{t}$ stands for time period (time is generally considered as a crop season).

\section{Total Employment Linkage $=$ Backward Linkage + Forward Linkage}

Measurement of employment. Farm and non-farm earning members were identified on the basis of 
time spent on farming or non-farming activities. Monthly employment can be measured in the following ways:

Farm Employment

$$
\begin{gathered}
\mathrm{FE}=\sum^{\mathrm{n}} \mathrm{A}_{\mathrm{i}} \\
\mathrm{i}=1
\end{gathered}
$$

Where

$A=$ Number of working days engaged by an economically active person in farm activities in a month

$i=$ Number of working member(s)

$\mathrm{FE}=$ Farm Employment per month

Non-Farm Employment

$$
\begin{gathered}
\mathrm{NFE}=\sum^{n} \mathrm{~B}_{\mathrm{i}} \\
\mathrm{i}=1
\end{gathered}
$$

Where

$\mathrm{B}=$ Number of working days engaged by an economically active person in non-farm activities in a month

$\mathrm{i}=$ Number of working member(s)

$\mathrm{NFE}=$ Non-Farm Employment per month

\section{Results}

\section{Farm and Non-Farm Employment Requirement for Aman and Boro Rice Production}

Farm employment requirement. Aman season covers the months of July to December, whereas Boro season spreads over the month of January to June. This research identified 17 farm activity variables for Aman rice production, which include land preparation, making and repairing plot boundaries, weeding, transplanting, application of manure, fertilizer, insecticide, pesticide, weedicide, harvesting and carrying crops to homeyard. For Boro rice 19 activity variables were identified. It revealed that production of Aman rice in one hectare of land, required a total of 112.31 mandays of farm employment, whereas for Boro rice a total of 144.32 mandays of farm employment was required to perform different farm activities as mentioned in Table 1. Boro rice production required more activity variables than Aman rice, because the former requires irrigation using shallow tubewells (STW) run by diesel fuel or electricity. Aman rice is usually grown on rain-fed conditions and hardly requires any supplemental irrigation.

Direct backward non-farm employment requirement. For crop production, farmers need different types of input, i.e., seed, ploughing, power tiller, tractor, manure, fertilizer, diesel, electricity, STW, electric motor, deep tubewells (DTW), insecticide, pesticide, weedicide, etc. To collect or purchase these inputs, farmers used family labour and/or hired labour. Besides, to operate plough, power tiller, tractor, STW, motor, DTW, they needed either their own service or employ paid operator. To carry the inputs from the markets, farmers needed transport workers for loading and unloading tasks. To apply inputs like seed, manure, fertilizer, insecticide, pesticide, weedicide in the crop field, they needed skilled labour either owned or hired. For making country ploughs, they needed carpenters services, and for making and repairing farm implements, they used services of blacksmiths. For STW, DTW, motor, power tiller, tractor repairing, they used services from mechanics. To collect or purchase spare-parts of these implements from the market places, they needed labour 
either owned or hired. To install or re-install of STW, DTW, and motor pump, they required mechanics. So, for crop production, the farmers required different non-farm inputs, and to collect, purchase, communicate, carry, install, operate, and repair these non-farm inputs, farmers needed to spend time by themselves or by hired labour, all of which was termed as direct backward non-farm employment. To produce Aman rice in one hectare of land, a total of 3.26 mandays of direct backward non-farm labour/employment was required for performing different non-farm activities. On the other hand, to produce Boro rice per hectare of land, a total of 16.91 mandays of direct backward non-farm employment was required for performing different activities (see Table 1).

Indirect backward non-farm employment. The input sellers, distributors, and service providers spent their time in selling, distributing, and after sale services. For example, in case of crop production seed dealer, power tiller/tractor traders, manure sellers, fertilizer retailers and dealers, pump owners and dealers, pump operators, insecticide, pesticide, weedicide dealers and retailers spent their time as well. Transport workers such as rickshaw pullers, van drivers, small truck drivers spent time to carry inputs used for crop production. Rural mechanics spent time on repairing farm machinary. Spare-parts shopkeepers spent time in selling their products.

To install or re-install tube wells and pumps mechanics also spent time. So, for crop production, the sellers, distributors, and service providers employed time by themselves or by hired/salaried labour, which was termed as indirect backward non-farm employment. To produce one hectare of Aman rice, a total of 12.83 mandays of indirect backward non-farm employment was required for different non-farm activities. Likewise, to produce Boro rice in one hectare of land, a total of 8.95 mandays of indirect backward non-farm employment was required for different activities (see Table 1).

Direct forward non-farm employment requirement. After harvesting and carrying the paddy from field to homeyard, a series of work such as threshing, winnowing, weighing, and packing activities were done by the farmers, either by themselves or by hired labour. The output of paddy was mainly used for consumption and for seed. If excess output remained after consumption, they sold it in the nearest urban/rural town or rural market places. The rice, which farmers consumed, involved processing activities such as wetting, boiling, drying, packing gunny bags, carrying to husking mill, husking, winnowing, etc. The female members of the households mainly do wetting, parboiling, and drying activities. Carrying to husking mill and husking activities were done by the male members of the family. Winnowing activities were done by the female members of the family. Activities like carrying of paddy and selling to markets were done by the male members of the family. So, after crop harvest, the farmers needed to spend time by themselves or by hired labour for carrying, processing, and selling crop output, all of which were termed as direct forward non-farm employment.

To produce Aman rice per hectare, a total of 40.01 mandays of direct forward non-farm employment was required for different farm activities. Besides, to produce Boro rice per hectare of land, a total of 54.46 mandays of direct forward non-farm employment was required for performing different activities (see Table 2).

Indirect forward non-farm employment requirement. Paddy or rice which was kept for home consumption required processing. After boiling and drying of paddy, transport vehicle like van, cart, rickshaw, trolley, or tractor carried paddy from home to the husking mill and bring husked rice back home. For husking 
purpose manager, chatal and Kuti labour, weighting labour, machine operators, and winnowing required. Paddy or rice which was sold to market also needed transport vehicle. So, after crop harvest, the transport operators, managers, weighters, machine operators, and other related persons spent time by themselves or by hired labour for carrying and processing crop output, which was termed as indirect forward non-farm employment.

To produce Aman rice per hectare, a total of 3.42 mandays of indirect forward non-farm employment was required for six different activities. For Boro rice production per hectare, a total of 7.95 mandays of indirect backward non-farm employment was required to perform different activities (see Table 2).

\section{Farm to Non-Farm Employment Linkages for Aman and Boro Rice Production}

Backward employment linkages. Farm to non-farm backward employment linkage is a ratio of direct plus indirect backward employment divided by the total farm employment requirement. The result of farm to non-farm backward employment linkage for Aman rice was 0.14, which meant that to produce one hectare of Aman rice, 14 mandays of employment was required from non-farm sector as backward support directly and indirectly to collect, purchase, carry, and sale of inputs, and to install, operate, repair of machineries and spare parts against 100 mandays of employment from farm sector. The farm to non-farm backward employment linkage for Boro rice was 0.18, which meant that to produce one hectare of Boro rice, 18 mandays of employment was required from non-farm sector for backward support directly and indirectly to collect, purchase, carry, and sale of inputs, and to install, operate, repair of machineries and spare parts, against 100 mandays of employment from farm sector. Farm to non-farm backward employment linkages for Aman and Boro rice crop together can be calculated by dividing the sum of the direct and indirect backward non-farm employment by the sum of farm employment for both Aman and Boro rice crop. The farm to non-farm backward employment linkage was 0.16, which meant that to produce Aman and Boro in a hectare of land within a year, a total of 16 mandays of non-farm employment was created as backward support against the requirement of 100 mandays of employment in farm sector activities.

Table 1

Farm to Non-Farm Backward Employment Requirement and Linkages for Aman and Boro Rice Crop

\begin{tabular}{llll}
\hline Employment status & Aman & Boro & Total \\
\hline Employment in farm sector & 112.31 & 144.32 & 256.63 \\
Direct backward employment in non-farm sector & 3.26 & 16.91 & 20.17 \\
Indirect backward employment in non-farm sector & 12.83 & 8.95 & 21.78 \\
Backward employment in non-farm sector & 16.09 & 25.86 & 41.95 \\
Farm to non-farm backward linkages & 0.14 & 0.18 & 0.16 \\
\hline
\end{tabular}

Note. Source: Field Survey (2007-2008).

Forward employment linkages. Farm to non-farm forward employment linkage is a ratio of direct and indirect forward employment divided by farm employment required per hectare of land. Farm to non-farm forward employment linkage for Aman rice was 0.39, which meant that to process and market Aman rice product from one hectare land, 39 mandays of employment was required from non-farm sector, against 100 mandays of employment from farm sector. Again, for Boro rice, the linkage was found 0.43 , meaning that for processing, carrying, and marketing of Boro rice per hectare land, 43 mandays of employment was required 
from non-farm sector, against 100 mandays of employment from farm sector. Farm to non-farm forward employment linkages for Aman and Boro rice crop is a measurement of direct plus indirect forward non-farm employment divided by the summation of farm employment for both Aman and Boro rice crop. The farm to non-farm forward employment linkage was 0.41 , which meant that for processing and marketing of Aman and Boro rice, a total of 41 mandays employment was required from non-farm sector, against the requirement of 100 mandays of employment from farm sector (see Table 2).

Table 2

Farm to Non-Farm Forward Employment Linkages for Aman, Boro and for Both Rice Crops

(Mandays)

\begin{tabular}{llll}
\hline Employment status & Aman & Boro & Both crop \\
\hline Employment in farm sector & 112.31 & 144.32 & 256.63 \\
Direct forward employment in non-farm sector & 40.01 & 54.46 & 94.47 \\
Indirect forward employment in non-farm sector & 3.42 & 7.95 & 11.37 \\
Forward employment in non-farm sector & 43.43 & 62.41 & 105.84 \\
Farm to non-farm forward linkages & 0.39 & 0.43 & 0.41 \\
\hline
\end{tabular}

Note. Source: Field Survey (2007-2008).

Total employment linkages. Total employment linkage is a summation of backward and forward employment linkage. The total linkage for Aman rice was 0.53 , which meant that to collect, purchase, sell, carry inputs, provide services, and for producing, processing, and marketing of Aman rice from one hectare of land, 53 mandays of employment was required from non-farm sector, against the requirement of 100 mandays of employment from farm sector. For Boro rice, total linkage was 0.61 , which meant that 61 mandays of employment was required from non-farm sector as backward support of collecting inputs required to produce Boro rice and forward activities like processing, carrying, and marketing of Boro rice products of a hectare of land against the requirement of 100 mandays of employment from farm sector. Farm and non-farm total employment linkages for both Aman and Boro rice crop can be calculated by dividing the direct and indirect total non-farm employment by the summation of total farm employment. Farm to non-farm total employment linkage was estimated as 0.58 (see Table 3). The farm to non-farm total employment linkage value of 0.58 meant production of Aman and Boro rice per hectare of land in one year, a total 58 mandays employment was required from non-farm sector as backward support and forward activities against the requirement of 100 mandays of employment from farm sector.

Table 3

Farm to Non-Farm Total Employment Linkages for Aman and Boro Rice Crop

(Mandays)

\begin{tabular}{llll}
\hline Employment status & Aman & Boro & Total \\
\hline Employment in farm sector & 112.31 & 144.32 & 256.63 \\
Direct backward and forward employment in non-farm sector & 43.27 & 71.37 & 114.64 \\
Indirect backward and forward employment in non-farm sector & 6.25 & 16.90 & 33.15 \\
Backward and forward employment in non-farm sector & 59.52 & 88.27 & 147.79 \\
Farm to non-farm linkages & 0.53 & 0.61 & 0.58 \\
\hline
\end{tabular}

Note. Source: Field Survey (2007-2008). 


\section{Employment Pattern}

\section{Month Wise Employment Patterns of Farm and Non-Farm Households Earning Members}

Earning members were engaged in farm and non-farm works. On average, farm and non-farm earning members got employment of 15 days and 26 days per month, respectively. Farm workers got employment on an average 21 days in the month of July. After this, farm employment rate per month began to reduce and dropped at six, five, and five days per month, respectively in the months of August, September, and October. During the month of July, farm employment availability rate was high, because of increased labour demand for Aman transplanting activity. Another reason was that Aman transplanting was more time-consuming activity than other farm activities, and for this reason more employment was required. After transplanting, different intercultural operations like weeding and application of fertilizers and insecticides were required, which was less time-consuming, and for this reason, farm employment rate decreased during the months of August, September, and October. The farm labour demand again increased and reached at 21 and 22 days per month on average in the months November and December. Aman harvesting started in the month of November and ended in December. Aman harvesting was also time-consuming activity and therefore, labour demand increased and employment availability reached the highest peak at 22 days in the month of December. In the month of January, labour demand again started to decrease and stood at 14 days per month on average. January was the interim period between Aman harvesting and Boro transplanting. Seeding of wheat broadcasting and vegetables cultivation activities started this time, which was less time-consuming and thus employment rate reduced but remained in medium position. Boro transplanting started in the month of February. As Boro transplanting by hand was time-consuming, the labour demand again increased in the month of February and employment stood at 25 days per month. Boro transplanting was a more laborious job than any other activities of crop production, because other activities were functionally linked with this activity. The interlinked activities included irrigation, manuring, and fertilizing, which were required just before transplantation of seedlings. For this reason, Boro transplanting required more time and reached at the highest peak period and employment rate stood highest at 25 days per month. After Boro transplantation, different intercultural operations of Boro rice were needed. The intercultural operations such as application of fertilizers, insecticide, and pesticide required less time and thus labour demand decreased and employment stood at eight and 12 days in the month of March and April, respectively. Although another intercultural operation like irrigation needed more time, this activity was mainly done by the farmers themselves and thus the opportunity of the landless wage labourers remained less. After April, Boro harvesting approached and labour demand started to increase in the month of May. Employment rate for Boro harvesting in the month of May stood at 22 days. Labour demand again decreased in the month of June and dropped at 15 days. June was the interim period between Boro harvesting and Aman transplanting. Boro rice processing activities were mainly done in this month and therefore employment rate remained 15 days per month. On the other hand, month wise non-farm employment availability varied less than farm employment. The availability of non-farm employment was not that flexible and varied from 25 to 27 days per month during the year (see Table 4, Figure 1, and Figure 2). The landless non-farm employment workers got an average employment opportunity 26 days per month. They got employment year round. Sales workers, service workers, production workers, transport workers, and labourers got employment 25, 30, 26, 28, and 24 days per month, respectively. The variation in non-farm employment among the non-farm workers was low. 
Table 4

Month Wise Employment and Income Patterns of Farm and Non-Farm Earning Members

\begin{tabular}{|c|c|c|c|c|c|c|c|}
\hline \multirow[b]{2}{*}{ Month } & \multirow[b]{2}{*}{ Farm work } & \multicolumn{6}{|l|}{ Non-farm work } \\
\hline & & Sales workers & Service worker & $\begin{array}{l}\text { Production } \\
\text { worker }\end{array}$ & $\begin{array}{l}\text { Transport } \\
\text { workers }\end{array}$ & $\begin{array}{l}\text { Labourer } \\
\text { and helpers }\end{array}$ & NF-total \\
\hline July & 21 & 26 & 30 & 27 & 29 & 25 & 27 \\
\hline August & 6 & 26 & 31 & 26 & 29 & 23 & 26 \\
\hline September & 5 & 25 & 30 & 26 & 28 & 23 & 26 \\
\hline October & 5 & 25 & 30 & 25 & 28 & 23 & 26 \\
\hline November & 21 & 26 & 30 & 25 & 28 & 22 & 26 \\
\hline December & 22 & 27 & 31 & 26 & 30 & 24 & 27 \\
\hline January & 14 & 27 & 27 & 27 & 28 & 25 & 27 \\
\hline February & 25 & 24 & 29 & 24 & 26 & 23 & 25 \\
\hline March & 18 & 22 & 30 & 24 & 29 & 24 & 26 \\
\hline April & 12 & 24 & 29 & 24 & 26 & 24 & 25 \\
\hline May & 22 & 26 & 30 & 27 & 26 & 25 & 26 \\
\hline June & 15 & 25 & 29 & 27 & 27 & 23 & 26 \\
\hline All average & 15 & 25 & 30 & 26 & 28 & 24 & 26 \\
\hline
\end{tabular}

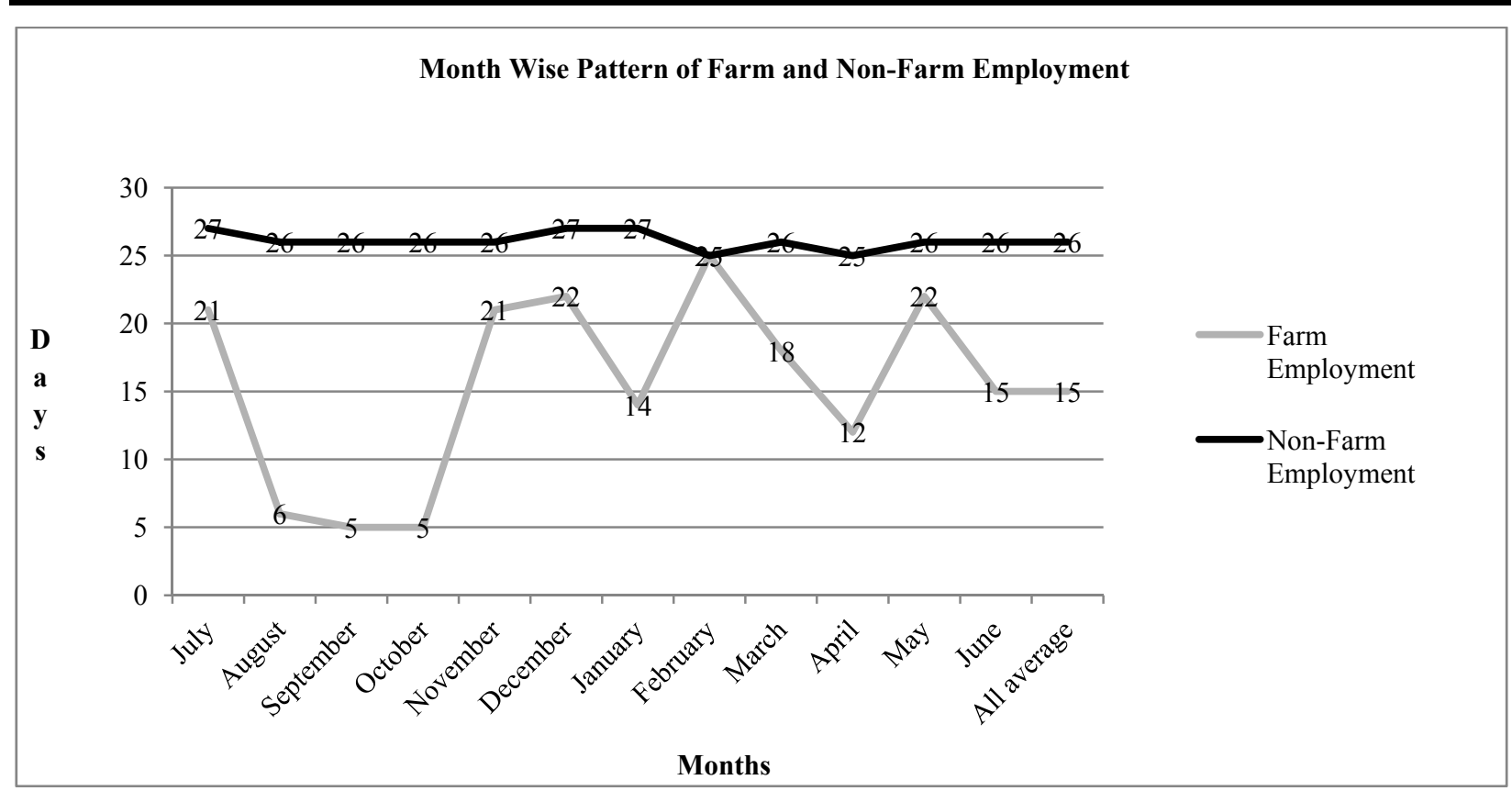

Figure 1. Month wise employment and income patterns of farm and non-farm earning members.

\section{Conclusions}

The findings imply that the farm to non-farm backward, forward, and total employment linkages for Aman and Boro rice were $0.16,0.41$, and 0.58 , respectively, which meant that a total of 58 mandays of employment was created in the non-farm sector for 100 mandays of employment in farm sector. The results showed that there was a positive relationship between farm and non-farm employment and that non-farm employment demand depended on the creation of farm employment. In other words, farm employment has direct and indirect influence on non-farm employment. 


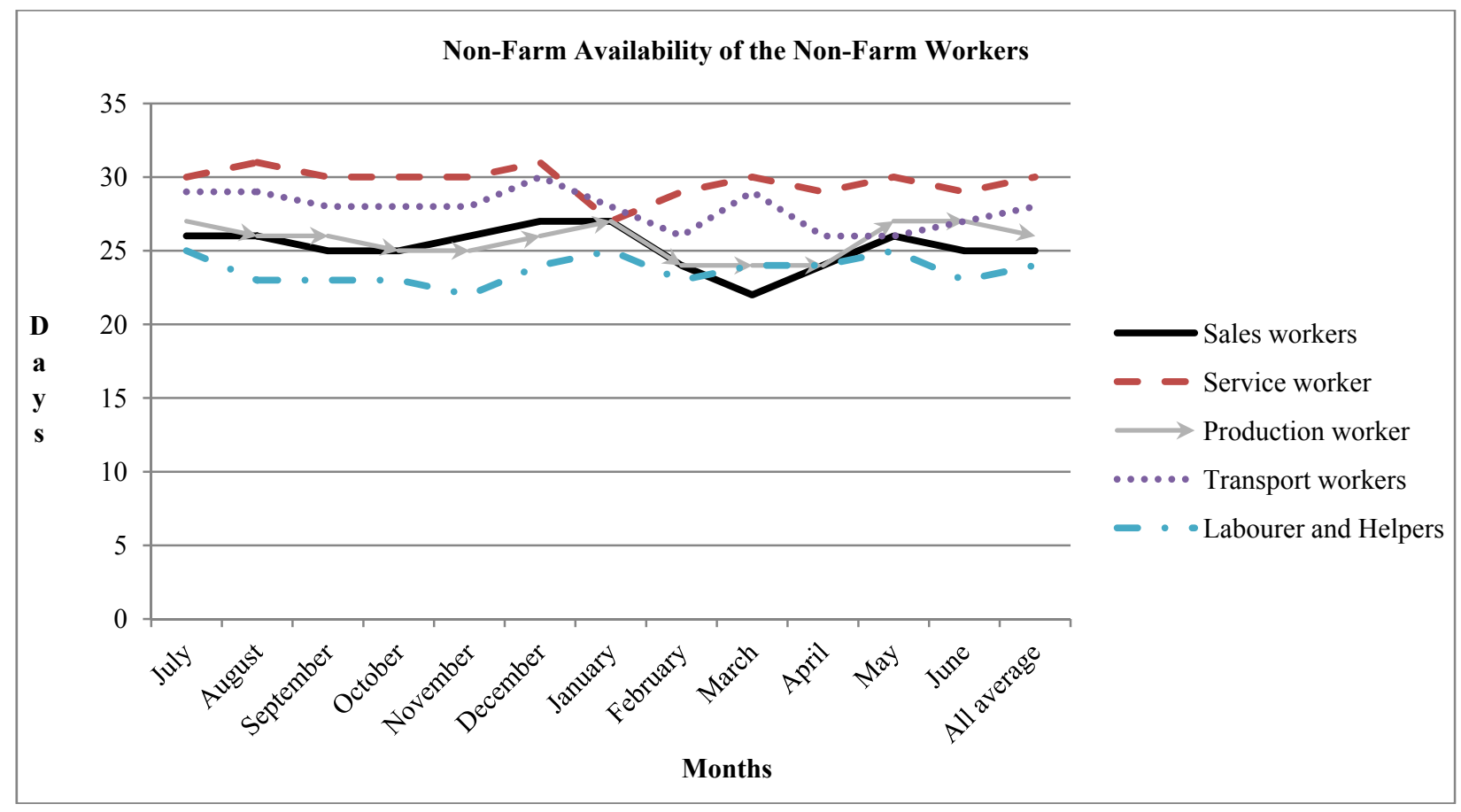

Figure 2. Month wise employment and income patterns of different non-farm professionals or workers.

Farm employment fluctuated more, compared to non-farm employment, mainly because the demand for farm labour increased significantly during the peak operations such as transplanting and harvesting of Aman and Boro rice. Non-farm employment increased during or after harvesting of Aman and Boro rice. The findings showed that non-farm employment remained better than farm employment.

The above empirical findings suggested that the interlinkage between the farm and non-farm sector was very strong. Such strong linkages imply that employment in non-farm sector can be substantially increased through accelerating agricultural development and agricultural policies should be made keeping in mind what additional products and services from non-farm sector would be required to keep pace with growing farm sector activities.

For stimulating rural non-farm sector employment, the following actions are suggested: (1) promote key small scale rural industries mainly to provide backward support such as manufacturing of agricultural machinery spare-parts and providing machine repair services, supplying workshop/industries including leather machine, maintain agricultural inputs and product supply chains as well as forward linkage industries, i.e., grain milling, packaging and marketing, crop storage and processing facilities, milk processing; (2) expand financial support for farm activities, as well as seasonal loan for workers engaged in different micro enterprises and small rural trades on easy terms and conditions; (3) promote non-crop enterprises like commercial poultry, rural aquaculture and dairy farming in the rural areas; (4) increase investment in agriculture including infrastructure development for productivity and efficiency gains so that non-farm employment can be boosted through backward and forward linkage effects; and (5) develop institutional links between agriculture and rural non-farm sector.

\section{References}

BBS (Bangladesh Bureau of Statistics). (1996). Report on labour force survey, 1995-1996. Bangladesh Bureau of Statistics, Statistics Division, Ministry of Planning, Government of the People's Republic of Bangladesh, Dhaka, Bangladesh. 
BBS (Bangladesh Bureau of Statistics). (2008). Report on labour force survey, 2005-2006. Bangladesh Bureau of Statistics, Planning Division, Ministry of Planning, Government of the People's Republic of Bangladesh, Dhaka, Bangladesh.

Haggblade, S., Hammer, J., \& Hazell, P. B. R. (1991). Modeling agricultural growth multipliers. American Journal of Agricultural Economics, 73(2), 361-374.

Hossain, M., Rahman, M., \& Bayes, A. (1994). Rural non-farm economy in Bangladesh: A dynamic sector or a sponage for absorbing surplus labour? SAAT working papers. New Delhi: ILO.

Mandal, M. A. S. (2003). Rural non-farm activities: Diversity and implications for rural labour market in Bangladesh. Employment and labour market dynamics - A review of Bangladesh development-2002 (pp. 229-249). Dhaka: Centre for Policy Dialogue.

Shilpi, F. (1998). The rural non-farm sector in Bangladesh: Polices, constraints and potentials. World Bank.

World Bank. (2004). Promoting the rural non-farm sector in Bangladesh. Report No. 29719-BD (Vol. II, main report). 